\title{
Opinions of Czechs about the Welfare State*
}

\author{
TOMÁŠ SIROVÁTKA** \\ Faculty of Social Studies, Masaryk University, Brno
}

\begin{abstract}
The post-communist countries are searching for social policies that would meet the requirements of social justice without hindering rapid development of market relationships. This article examines the links between three levels of legitimacy of the concept of the welfare state: the level of preferred principles, the level of attitudes toward specific policies, and the level of desired solutions. It is based on two representative surveys of the Czech population, carried out in 1998 and 1999, on family budgets data from 1989 to 1998, and on some international comparisons, in particular with the Netherlands. The author attempts to explain why and in what respect Czech citizens consider the current social policy to be ineffective: it is mainly owing to the perceived lack of reciprocity between its benefits and its costs, and because individual gain is the predominant motivation behind support for social policy among the great majority of Czech citizens. The author claims that this causes them to lose trust and interest in the government's social policy and leads them to search for other, more efficient solutions through private insurance systems, which promise them protection against growing social uncertainty while providing less solidarity.
\end{abstract}

Sociologický časopis/Czech Sociological Review, 2002, Vol. 38, No. 3: 327-344

\section{Introduction}

The issues concerning the legitimacy of the welfare state, and its importance for the legitimacy of the social and political system, have long been in the spotlight of the discussion on the current development of the welfare state. This discussion clearly demonstrates that citizens strongly support the general principles and measures of the welfare state in (post)modern society. However, somewhat volatile opinions have formed over the question of the desired type of social policy and its specific measures: what matters is the political affiliation, class (social group), or labour market status of the respondents, as well as the type of social policy programme. Owing to the way actual changes in policies are reflected, the opinion on specific measures is also dynamic over time [cf. particularly TaylorGooby 1985, Ringen 1987, Taylor-Gooby 1991, van Oorschot 1997, Svalfors and TaylorGooby 1999, Svalfors 1999].

In post-communist countries, the legitimacy of principles and individual measures of social policy appear to be even more important owing to the fact that the criteria of social (distributive) justice are being redefined over the course of the social transformation [Matěju

\footnotetext{
* The research that made this paper possible has been supported by the Grant Agency of the Czech Republic (Project No. 403/98/1085).

** Direct all correspondence to: Tomáš Sirovátka, Institute for Social Issues, Faculty of Social Studies, Masaryk University, Gorkého 7, 60200 Brno, phone + 4205 41615206, e-mail: sirovatka @fss.muni.cz
} 
1997] and the social policy measures are being rebuilt accordingly. In the process of the 'recommodification' of life under enormous economic and social pressures, the overall scope of redistribution however has been limited. Consequently, as surveys in the Czech Republic have shown, the public has adopted a quite critical view of the current social policy [Purkrábek 1996, Sociální... 1998, Rabušic and Sirovátka 1999, van Oorschot, Sirovátka, and Rabušic 1998]. However, demands for increasing the range of social benefits have not been made with regard to all social policy programmes. Also, the link between the legitimacy of social policy and the legitimacy of the political elites, the political system and overall political stability has not been very strong in the Czech Republic, as the political preferences of voters appear to be relatively stable - at least in terms of the left-right dichotomy of the political spectrum [Vlachová 1999]. In this paper, we will try to examine what it is that Czech citizens actually expect of their welfare state, and how these expectations correspond to the more general preferences of the public, and to the experiences the Czech public has had with actual social policies.

\section{Research Questions and Data}

The concept of social policy and its related demands tend to take shape in the minds of citizens on at least three levels. The first level consists of its basic principles, i.e. solidarity and its motives, as well as overall perceptions of social justice. The second level involves its specific solutions, i.e. how the citizens view the current social policy programmes and their legitimacy. The third level entails the notion of legitimate and desired solutions, which result from a confrontation between the principles and the reality of the social policy and its programmes.

Three questions consequently arise: What are the main principles of a just and legitimate social policy that the Czech public cherishes? How are the current social policy in general, and its individual programmes in particular, viewed by citizens? Which specific solutions and measures of social policy are citizens willing to support? If it is assumed that the legitimate concept of the welfare state determines the actual type of welfare state in a democratic society, such questions are of paramount importance. ${ }^{1}$

The data presented here are drawn from the Czech representative surveys entitled 'Impacts of Social Policy Transformation' (June 1999; 1319 respondents) and 'Legitimacy of Social Security' (June 1998; 1351 respondents), which the author conducted in co-operation with the Institute for Public Opinion Research (IVVM). These surveys were inspired in part by the Dutch TISSER Solidarity Study [van Oorschot 1998], and several questions in the Czech surveys were adopted from the Dutch one, which enabled a comparison to be made of the two countries. In addition, an analysis is made of the Family Budget Surveys, collected by the Czech Statistical Office for the period of 1989-1998.

A comparison of the social policy of the Czech Republic and that of the economically much more developed Netherlands is feasible and may contribute to a better under-

\footnotetext{
1/ The classification of the welfare state is actually based on this assumption. Citizens end up with the type of welfare state they support through their political preferences, as the modern state is democratic by institutionalising the principle of opposition. However, the legitimacy issue remains a permanent problem [cf. Habermas 1976].
} 
standing of the factors that influence the formation of claims made on the Czech welfare state. Despite the social, cultural, economic and political differences between these two countries, the transformation of social policy during the past ten years has followed a similar pattern in both countries. This trend has led to restricted generosity and weakened solidarity, with an emphasis on greater individual responsibility. The level of social protection benefits (as replacement rates to wages) has dropped and the benefits have become less entitlement-oriented and more income-tested [van Oorschot, Sirovátka, and Rabušic 1999].

\section{Some Hypotheses about Citizens' Support for Social Policy}

According to Habermas, the level of principles is more important for policy legitimacy than the level of evaluation of specific policies, as legitimacy conflicts of a political system develop mainly over the issue of principles [Habermas 1976]. On the other hand, the legitimacy of principles may be weakened by a low degree of effectiveness of specific programmes and of the institutions that are supposed to enforce these principles [Ringen 1987]. Thus it is necessary to focus both on the preferred principles and goals and on the actual and desired solutions.

The changing support for the basic principles of the current welfare state may be perceived from a number of perspectives. Here, attention is paid mainly to those seemingly of increasing relevance for the post-communist countries in the process of transformation. Rose and Peters [1978] assert that public support for social policies declines in periods of economic recession, when real incomes decrease. This particularly relates to the middle and upper income categories of respondents. Wilenski [1975] predicted that a new 'middle mass' - rising as a result of economic development, the growth of new industries, and expanding educational opportunities - would refuse to pay taxes since they would see no benefits for them in the welfare state. Changes in social policy accompanied by an increase of social inequalities also affect the support given to the principles of the welfare state. According to some researchers, the welfare state became popular, particularly among the middle class, when it was flourishing most strongly [Baldwin 1990]. Hence the more recent decrease in benefits (and their increased targeting) is expected to erode its foundations. Offe [1996: 176] points out that “...'flat rate' policies would alienate the better-offs whose income would be used to subsidize the transfers to the well-to-do.“

Similarly, we have to take into account the decisive role that the media and public opinion leaders play. Here, the hypothesis of 'issue attention cycles' may be worth considering, particularly given the neo-liberal ideology that asserted itself in the public debate during the first few euphoric years of transformation. ${ }^{2}$ Finally, economic shortages and striving for individual consumption (the scarcity hypothesis) in the post-communist coun-

\footnotetext{
2/ According to Pettersen [1995: 202], Anthony Downs' theory of 'issue attention cycles' seems appropriate for analysing the changes of the 1970s and 1980s when the 'new right' movement was initiated and grew in vitality. This theory explains that attitudes of the public on political issues (including welfare state) are cyclical being influenced by an introduction of the political novelties by opinion leaders and mass media.
} 
tries may lead the public to reject the principle of collectively sharing risks which are in fact individually diverse. ${ }^{3}$

Based on the above assumptions, one could expect that during the transformation period general public support for generous social policies (which were in place in the past) would fade. On the other hand, one could also expect that some public expectations regarding the welfare state would increase owing to the need to absorb transformation risks [Offe 1996]. In either case, growing social inequalities and an unequal distribution of transformation risks can be expected to differentiate society in many respects: in the support for solidarity and the principles of social policy, in the evaluation of existing social policies, and in the expectations from the welfare state.

\section{Support for the Principles of Social Policy}

\section{Solidarity and sharing the risks}

Van Oorschot [1997] identified four main motives of solidarity: first, belonging to and identifying with a community; second, moral obligation towards the needy members of a community; third, individual long-term self-interest; and finally, an accepted authority (enforced by the authority). The principle of solidarity that constitutes the basis of social policy enjoys significant support in Czech society. The support is based on all the above-mentioned motives of solidarity. Their relative strength and ranking resemble the situation in the Netherlands in the mid-1990s. Like the Netherlands, individual self-interest is the strongest solidarity motive in the Czech Republic.

All the motives that underpin solidarity are relatively strong in Czech society as a result of a widespread feeling of threat from the transformation risks: uncertainties caused by the changing labour market and growing unemployment, a long-term decrease or an insignificant increase in real incomes, the relatively common feelings of subjective poverty and, the loss of significant savings or financial assets suffered by many citizens in the bankruptcies of banks or investment funds. That the structure and the strength of the motives are similar throughout the social strata, irrespective of the political preferences of respondents, could serve to confirm the hypothesis of a general threat (regardless of individually diverse social risks) ${ }^{4}$

However, the predominant motive of the expected individual benefit to be had from the welfare state may weaken attitudes of solidarity and the requirements for broad collective protection against risks and uncertainties. According to Offe [1996], when differences in people's opportunities are on the rise and an economic crisis sets in, the rational

\footnotetext{
${ }^{3 /}$ In accordance with the European Value Study, the post-materialism index equalled 2.01 in the Czech Republic in 1991 while the average for the West was 2.56 [cf. Ester, Halman, and de Moor 1994: 214]. This finding fits to the scarcity hypothesis (material deprivation strengthens the effect of material values).

4/ It has been emphasised that social cohesiveness and solidarity becomes stronger when in jeopardy. The welfare policy was born due to deprivation and a need for collective protection from risks faced by modern society [cf. Heclo 1981]. This explains the willingness to share individually diverse risks irrespective of existing social differences.
} 
Table 1: Solidarity motives (\% of positive answers)

Question: 'Paying taxes and social security contributions is compulsory. However, people may have different reasons for paying them. To what extent do you agree/disagree with the following reasons? Do you pay social security contributions and taxes because of...?*

\begin{tabular}{lcc} 
& $\begin{array}{c}\text { Czech Republic } \\
1999^{* *}\end{array}$ & $\begin{array}{c}\text { Netherlands } \\
1995^{* * *}\end{array}$ \\
\hline Potential (future) individual benefit & 78 & 82 \\
Moral duty to the needy in society & 61 & 64 \\
Sympathy for the lot of beneficiaries & 59 & 42 \\
Benefit to society & 56 & $\mathrm{n} / \mathrm{a}$ \\
\hline
\end{tabular}

* In addition to the motives presented by van Oorschot, the motive of contributions being beneficial to society is used (e.g. the notion of solidarity as an investment into the future of society, i.e. its productive function, integrity, etc.). No question was presented on the forced solidarity that results from accepting the authority of the state.

** Data from June $1999(\mathrm{~N}=1,319)$.

*** TISSER Solidarity Study $1995(\mathrm{~N}=1,403)$.

Table 2: Willingness to redistribute the individually different risks: Which groups should pay higher contributions to social security? (\% of negative answers) Question: 'Do you think that people in the following categories should pay higher contributions to social security and/or higher taxes?'

\begin{tabular}{lcc} 
& Czech Republic & Netherlands \\
& 1999 & 1995 \\
\hline Employers in sectors suffering from higher & 40 & 62 \\
unemployment rates & 61 & 76 \\
$\begin{array}{l}\text { People with higher risks of unemployment } \\
\text { Workers in sectors with higher unemployment rates }\end{array}$ & 65 & $\mathrm{n} / \mathrm{a}$ \\
$\begin{array}{l}\text { Employers in sectors with higher sickness and invalidity } \\
\text { People facing a higher risk of sickness and invalidity due }\end{array}$ & 31 & 40 \\
to their life-style & 34 & 41 \\
$\begin{array}{l}\text { People facing a higher risk of sickness and invalidity due } \\
\text { to their job }\end{array}$ & 59 & 59 \\
$\begin{array}{l}\text { People facing a higher risk of sickness and invalidity due } \\
\text { to their biological/genetic determination }\end{array}$ & 71 & 80 \\
$\begin{array}{l}\text { Women because on average they live longer than men } \\
\text { Pomen }\end{array}$ & 82 & 89
\end{tabular}


motivation of solidarity gives way to individualistic attitudes. The rise in social inequalities, the differentiation of social risks, and the reformulation of social policy, away from universalism and toward benefit targeting, all take place at the same time within the transformation period. As a result, in comparison with developed market democracies, the consequences are more intense and have a more significant impact on the perception of opportunities in life. The foundations of solidarity that constitute the basis of the welfare state are thus subject to a number of pressures. ${ }^{5}$ Therefore, even though solidarity enjoys strong support at the level of principles, the willingness of Czech citizens to share and redistribute individually differing risks through social policy measures is rather low at the level of specific programmes. This fact stands out clearly in comparison with the Netherlands. Unique to the Czech Republic is that the distribution of these attitudes throughout different social strata is quite similar, irrespective of the political orientation of respondents.

\section{Social justice}

According to Miller [1976], the imperative of social justice is always comprised of several principles: rights (guaranteed and equal individual rights and freedoms for everybody), deserts, and needs. Different societies attribute different weight to each of the above principles in their contribution to social justice. ${ }^{6}$ Deutsch [1975] defines several principles of distributive justice, such as equity, equality and need, i.e. reciprocity, equality and neediness. These principles may be considered as complementing one another. For example, in social policy, reciprocity is emphasised more strongly in social insurance systems, whereas equality is stressed more in providing defined categories of the population with 'demogrants' (child benefits, services or social benefits provided to the large groups or to the public), while neediness is accentuated in social assistance programmes (which provide entitlements based on income or other specifically defined handicaps). The above principles are also to some extent competing with each other. The question is which one will be the strongest. Matěju [1997] emphasised the initial 'split of consciousness' and only a gradual crystallisation of the legitimate principles of distributive justice in the post-communist societies.

The analysis confirms that, with respect to the preferred aspects of social justice in social policy programmes, the Czech public supports different and sometime contradictory principles of social policy at the same time. However, the emphasis placed on individual principles differs according to the type of social policy programme. In general, the principle of need is stressed rather strongly, as is the guarantee of a minimum standard of

\footnotetext{
5/ Ferge [1997] mentions the process of the 'individualisation of the social'.

6/ The Relationship between these principles and the egalitarianism requirement is not simple. There are two core issues in social policy: the provision of equal opportunities and a decrease of inequalities of outcomes, guaranteeing a minimum standard. Its level is, however, subject to discussion. Both of these goals are to some extent related to the principle of need and the principle of rights. In addition, the libertarian requirement of individual freedom is also egalitarian in a sense, by virtue of demanding equal rights to individual freedom for everybody [on ideas of egalitarianism see particularly Sen 1992].
} 
Figure 1: Goals - principles of providing selected welfare benefits

The question was: 'Different people believe that social security benefits should follow different goals. Which goals do you think should be followed?' (Data from June 1999).

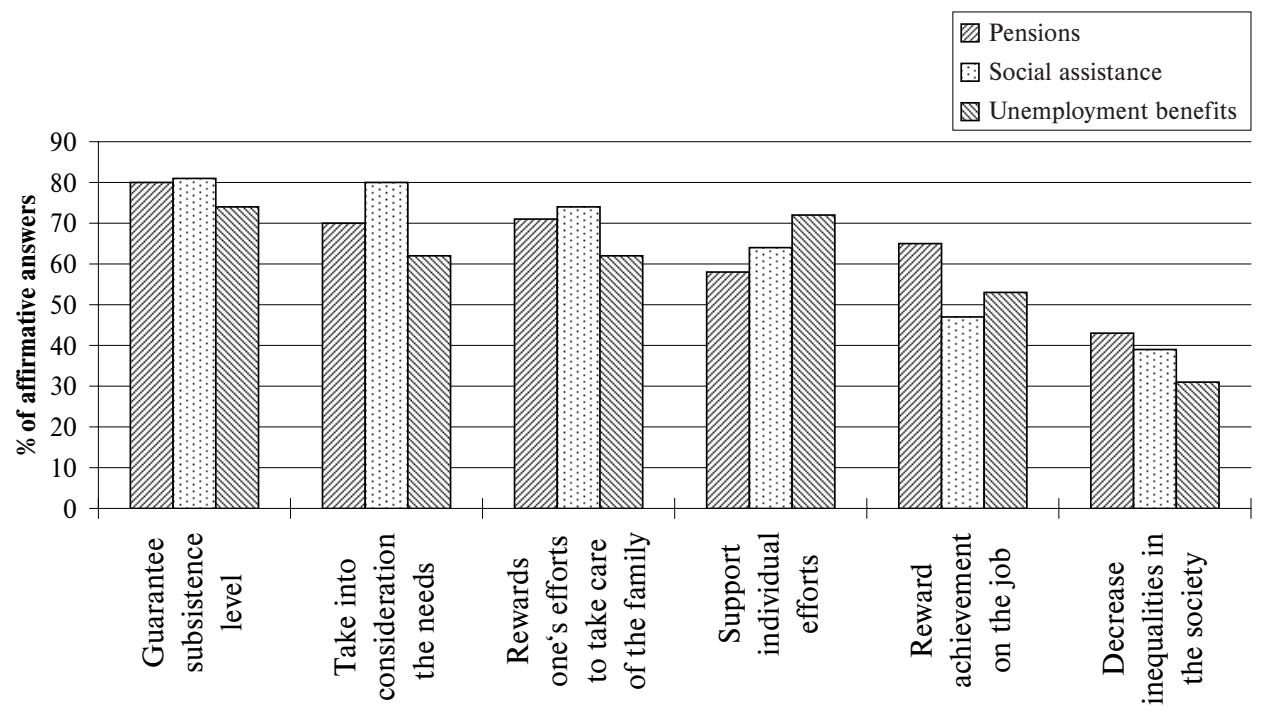

The goal of providing the benefits

living (subsistence level). However, the principle of deserts (in terms of social reciprocity) is also stressed very strongly, articulated in terms of high personal merit, such as taking care of the family and exerting individual efforts. On the other hand, the principle of decreasing inequalities of wealth is emphasised less strongly. This configuration of preferred principles - goals of social justice among Czech respondents - reveal an inclination towards a concept of a rather 'limited' welfare state at the level of principles. ${ }^{7}$

The structure of the principles applied in social assistance does not differ significantly from the structure of principles related to social insurance (pensions and unemployment benefits). They do differ in the stronger emphasis on job achievements with regard to pensions, the stronger emphasis on needs with regard to social assistance benefits, and the stronger emphasis on individual efforts with regard to unemployment benefits. These modest differences correspond largely to the character of the particular benefits.

The emphasis the Czech public places on the principles of need, the guarantee of minimum subsistence, and individual effort and reciprocity, combined with less of a stress on the principle of decreasing inequality, may stem from a realistic awareness of the restricted resources available for social policy programmes (while demands to expand the scope of interventions are rising) among the respondents. This conforms to the hypothe-

\footnotetext{
7/ In this case, we prefer not to use a notion of liberal or residual welfare state because this notion includes other dimensions than only the principles or purposes underlying the delivery of the benefits.
} 
sis concerning the significant impact of the economic recession in the Czech Republic from 1997 to 1999 (the second period of GDP decline after 1990). With regard to the hypothesis of 'issue attention cycles', it might be worth noting that the social policy strategy had been presented to Czech citizens, at least up until 1993, as a form of assistance provided to the 'needy', i.e. as a social safety net, and not as a matter of a right to an entitlement.

\section{The Evaluation of Czech Social Policy by the Public}

\section{Development of social policy and the level of expenditures}

In general, the Czech public perceives the recent changes in social policy as a deterioration, and the current level of social policy expenditures as low.

More than half of the respondents stated that the social policy had deteriorated since 1990, and found the government social policy expenditures too low (one-third of respondents were unable to answer these questions). Only $10 \%$ of citizens stated that the social policy has improved, even though this percentage was somewhat higher for health care and pensions. Only $4 \%$ of citizens found the social policy expenditures relatively high. Housing support, employment policy and health care were subject to the most severe criticism (deterioration in the given area and the insufficient provision of funds in this area).

The respondents' evaluation of general trends in social policy and of the overall level of social policy expenditures correlates with their subjective feeling of poverty, their selfranking in the social strata, and, above all, with their political orientation. People who feel poor, members of lower social strata, and respondents who support left-wing political parties take a more critical attitude to social policy trends and the level of social policy expenditures. ${ }^{8}$ However, the percentages of the negative evaluation of social policy developments and, in particular, the current level of social policy expenditures, are relatively high overall, even among well-established citizens and supporters of right-wing parties.

\section{Individual gains and losses stemming from social policy measures}

Given the fact that individual self-interest is predominant among solidarity motives, we also need to focus on the individual gains and losses that stem from the social policy measures. While disregarding the one-fourth of respondents who were undecided, five times more respondents felt that they had lost as a result of the social policy changes in the Czech Republic (almost half of all respondents) than those who felt that they gained. The strength of this feeling of loss as a result of redistribution through social policy measures may be surprising. By comparison, the ratio of negative answers to the same question in the Netherlands was only slightly higher than that of the positive answers, while feelings of balanced gain and loss prevailed in the opinions of Dutch citizens.

${ }^{8 /}$ The Spearman's coefficient of correlation between the preference for a political party on the leftright scale and the evaluation of social policy development equalled 0.29 (significance 0.000 ). The correlation between the preferred party and opinion on the social policy expenditures equalled 0.26 (significance 0.000). 
Table 3: Evaluation of changes in social policy and of the current level of expenditures (\% of negative answers; 'I cannot tell' in parentheses)

Question: 'How has the situation changed since 1990 in the following areas?' and'What is the current level of government expenditures like in the following areas?',

Czech Republic, June 1999 ( $N=1,319)$

Area

Housing support

Employment policy

Pensions and security for the elderly

Healthcare

Family related benefits

Education development

Unemployment benefits

Illness, injury and disability benefits

Guaranteeing subsistence level

Social policy in general
The level (significantly) deteriorated

$54 \quad(23)$

$53 \quad(27)$

$43 \quad(17)$

$42 \quad(6)$

$39 \quad(28)$

$38 \quad(20)$

$36 \quad(41)$

$35 \quad(21)$

$32 \quad(30)$

$56 \quad(13)$
The level of expenditures is

(very) low

$62 \quad(22)$

52 (27)

$41 \quad(15)$

$55 \quad(9)$

$46 \quad(24)$

$49 \quad(20)$

34 (29)

52 (19)

$36 \quad(29)$

$59 \quad(16)$

Figure 2: Evaluation of social policy by political orientation

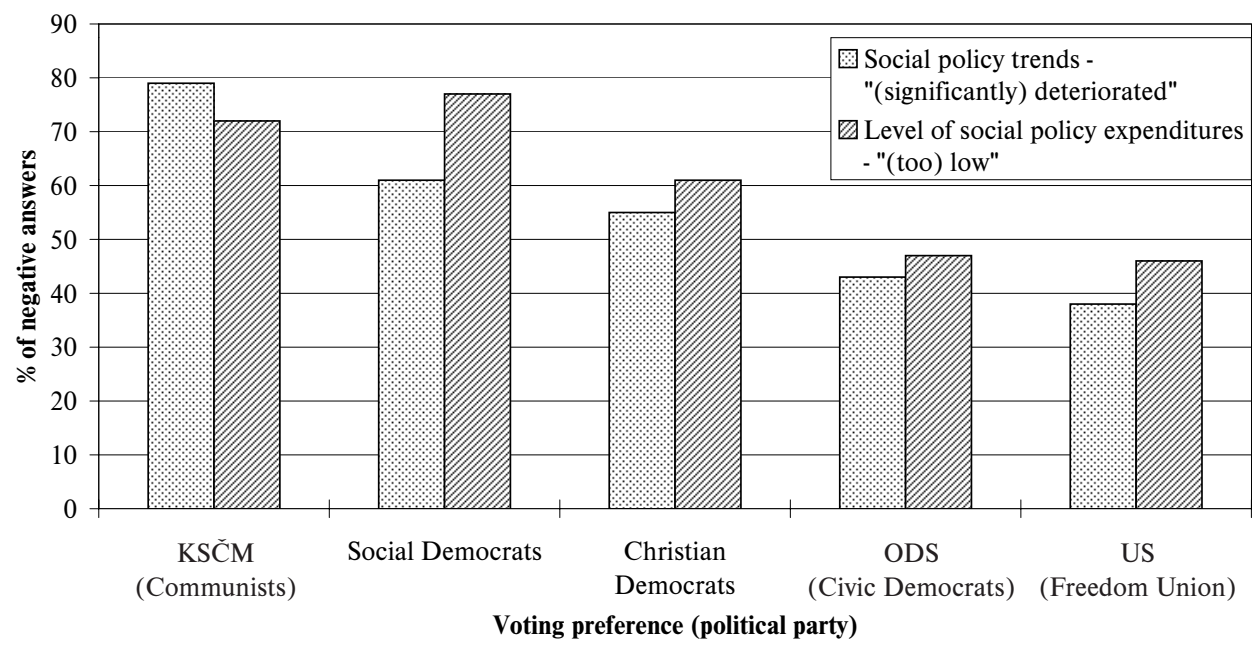

Note: Data from June $1999(\mathrm{~N}=1,319)$. 
In contrast to the differences in the evaluation of the social policy trends and the level of social expenditures based on political and class affiliation, in the Czech Republic the mostly negative evaluation of individual gains and losses was not affected by political orientation, subjective feelings of poverty, or by the self-ranking of respondents among the social classes.

Feelings of individual loss as a result of social policy may help to explain the prevailing negative evaluation of the developments in Czech social policy and of the current level of its benefits. Two objective circumstances seem to be important in this respect, the first of which is the overall generosity of social policy. The share of social expenditures in GDP in the Czech Republic and the Netherlands differs sharply: 20-22 per cent in the Czech Republic in the long run, and 29-30 per cent in the Netherlands; the level of most benefits relative to wages is lower in the Czech Republic [van Oorschot, Sirovátka, and Rabušic 1999]. The second reason is probably more important. In the Czech Republic, the social strata with the lowest incomes have suffered a decrease in their real incomes during the 1990s when compared to 1989, and this loss has only been partially compensated by social security benefits. Due to a relative increase in the tax burden and social security contributions, compared to the social benefits provided by the social policy system, the middle-income groups lost the most in relative terms during this period [Sirovátka 1998, Večerník, Burdová 1999]. These losses were a result of the diminished average real value of benefits provided to the family and the diminished average relative value of social insurance benefits when compared to wages, while the shares of the income tax and social security contributions in the gross real income of employees have increased only slightly.

The Czech population could rightfully anticipate (in line with the liberal principles of social justice declared by the highest political representatives) the elimination of universal social security policy provisions and the generally decreased availability of social benefits. However, having been presented with liberal policy promises ('more money in the pockets of citizens and less money redistributed by the state') the Czech population was not prepared for such a remarkable deterioration in the ratio between the payments it made to the state and the social security benefits received from the state. Their trust in the ability of the government to use taxes and social insurance contributions properly and effectively in social policy was weakened as a result.

\section{The administration of social policy and the trust of the public}

Solidarity, whether based on a common identity, the mutual usefulness of citizens, or a rational calculation of individual benefits, may give social policy its strong foundations, but only on the condition that the participants in the collective protection system trust each other. In addition to this mutual trust, trust in the state is also very important, as the state acts as the guarantor or the manager of the system by being able to suppress the potential individualistic tendencies that could harm others [Ringen 1987].

It is a widespread belief in the Czech Republic (but not only there) that the beneficiaries of social security benefits abuse them. This is particularly the case with respect to the unemployment benefits provided to the people who are working in the 'grey economy'. In contrast to the Netherlands, however, respondents in the Czech Republic do not anticipate as much abuse of other social security benefits, most likely owing to the fact that 
Table 4: Are you personally gaining or losing as a result of the social policy?

Question: 'Thinking about all the benefits and advantages resulting to you from the government social policy on the one hand, and about the taxes and social security contributions you are paying on the other hand, do you think you are gaining or losing?'

\begin{tabular}{lccc} 
& $\begin{array}{c}\text { (Definitely) } \\
\text { Gaining }\end{array}$ & $\begin{array}{c}\text { Neither gaining } \\
\text { nor losing }\end{array}$ & $\begin{array}{c}\text { (Definitely) } \\
\text { Losing }\end{array}$ \\
\hline Czech Republic 1999 & 9 & 23 & 46 \\
Netherlands 1995 & 21 & 37 & 29 \\
\hline
\end{tabular}

Note: The answer 'undecided, I cannot tell' represents the percentage remaining to reach $100 \%$.

Figure 3: Social transfers compared to taxes and social security contributions by deciles from 1989 till 1998 (in \%, employees' households only)

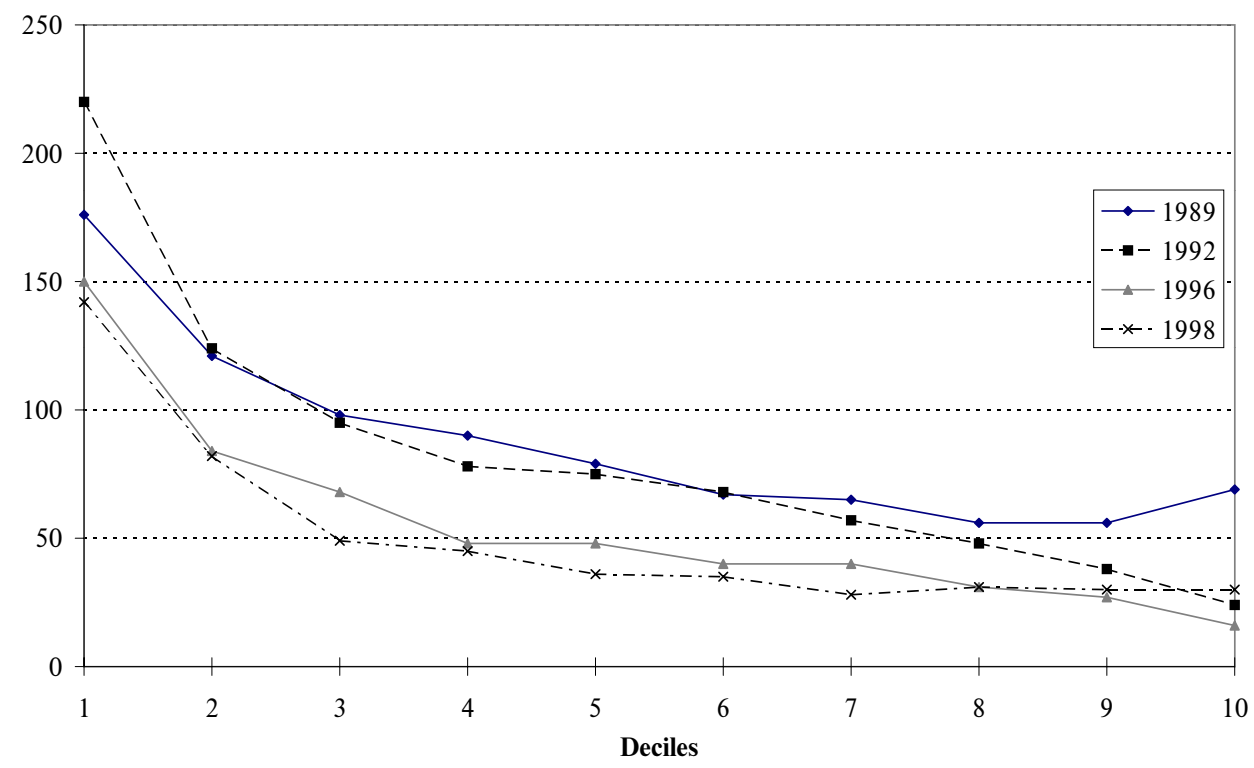

Notes: Total taxes and social insurance contributions for each decile $=100$. Deciles based on the net disposable household income per capita.

Source: Czech Statistical Office; Family Budgets 1989-1998; own calculations. 
Table 5: Misuse of social security (welfare) benefits (\% answers of often or very often) Question: 'How frequently do you think people abuse social security benefits?'

\begin{tabular}{lcc} 
& Czech Republic & Netherlands \\
The type of benefits & 1999 & 1995 \\
\hline Unemployment benefits & 54 & 46 \\
Disability benefits & 34 & 50 \\
Social assistance benefits & 30 & 43 \\
Child benefits & 23 & 22 \\
Old-age pension benefits & 10 & 4
\end{tabular}

Question: 'How often do the following situations occur?'

\begin{tabular}{lcc} 
Kind of misuse of benefits & $\begin{array}{c}\text { Czech Republic } \\
1999\end{array}$ & $\begin{array}{c}\text { Netherlands } \\
1995\end{array}$ \\
\hline Benefit recipients are working illegally & 54 & 72 \\
The unemployed are too passive when looking for a job & 49 & 50 \\
People find it easy to take sick days & 37 & 52 \\
People hide cohabitation to be eligible for benefits & 36 & 52 \\
It is too easy to be deemed disabled & 12 & 50
\end{tabular}

Czech social security benefits are less generous and attractive, and there are stricter procedures in place for claiming them.

Also, the quality of management of the social policy system is evaluated in the Czech Republic as mostly negative. This fact has significant implications for the perception of social justice in the social policy system, as well as for the evaluation of its cost-effectiveness. In June of $1998,67 \%, 61 \%$ and $59 \%$ of respondents considered the system to be too costly, poorly managed, and unjust respectively. In the Netherlands, the responses to similar questions were significantly lower: 57\%, 37\% and 30\% [van Oorschot, Sirovátka, and Rabušic 1999].

\section{Preferred Solutions}

If self-interest is predominant among the motives of solidarity, if the willingness to share risks collectively is not high among the Czech public, and if the feelings of individual losses stemming from actual social policies and of dissatisfaction with these policies tend to prevail among citizens, what solutions would the Czech public prefer in the area of social policy?

According to Večerník [2002: 11], the Czech population has a tendency to support increases in welfare state expenditures and taxes as opposed to decreasing them. It appears that the expectations of the Czech public related to redistribution by the state would be difficult to meet. If they were met, these expectations could indeed lead to an increased tax burden or social insurance contributions, with all the ensuing negative impacts (i.e. increasing labour costs, inflation pressures, rising unemployment, limited investment funds and a slowdown in economic growth). 
Table 6: Requirements of citizens concerning the relationship between social security contributions and benefits (\% of negative answers)

Question: 'Would you agree to significantly higher benefits/standard for those who pay higher contributions to the social security fund?'

\begin{tabular}{lcc} 
Benefit & Czech Republic 1999 & Netherlands 1995 \\
\hline Old-age and disability pensions & 27 & 59 \\
Sickness benefits & 30 & 56 \\
Unemployment benefits & 37 & 53 \\
Healthcare standard & 47 & n/a
\end{tabular}

However, when the question was posed in a different manner, so as to correspond to the choices the government makes in the area of social policy, ${ }^{9}$ we discovered that the Czech public's support for an increase in welfare state expenditures is actually not that high. The public evinces a strong realistic attitude, and proves itself aware of the number of economic restrictions on welfare state expenditures, though they might be desirable in some areas. Moreover, the Czech public has experienced losses as a result of the social policy over the course of the past few years. ${ }^{10}$ Therefore, it prefers the option of avoiding an increase in taxes and approves the increase in welfare expenditures only on the condition that savings be made in other areas. When asked this question, 56\% of the Czech population agreed with the above-mentioned option, while only $17 \%$ of the public opted for increases in welfare expenditures even at the cost of increasing taxes, and $8 \%$ selected cutting down on taxes even at the cost of reducing welfare benefits. Neither social class nor the political orientation of respondents had an effect on these expressed preferences. By the same token, the fact that citizens believe expenditures in a given social policy area to be insufficient does not necessarily mean that they want these expenditures to rise.

The types of social policy benefits and the deservingness of different social groups also play a crucial role in the opinions of the Czech public when making their claims on the welfare state. Even though the average level of all types of social security benefits, when compared to wages and total household income, was decreasing over the course of the 1990s (except for pensions), as many as $70 \%, 63 \%$ and $56 \%$ of Czech citizens called for increases in child benefits, parental benefits and sickness benefits respectively. However, less than $50 \%$ supported increases in old-age pensions, $45 \%$ increases in social assistance benefits, $36 \%$ increases in social benefits, housing benefits and widow(er)s' pensions, and only $27 \%$ of respondents demanded an increase in unemployment benefits [Rabušic and Sirovátka 1999].

While the demands related to expenditures on social policy are not extraordinary, what the Czech public is actually demanding is reciprocity between the gains derived from the social policy system and the payments made to the system. In this respect, they show less support for redistribution within the system than the population in the Netherlands.

\footnotetext{
9/ Actually, the choice is not as simple as making a decision between higher taxes/higher social expenditures or lower taxes/lower social expenditures. The tax revenue is also used for other public policies, such as state admninistration, defence and other public goods. Therefore, it is a matter of the choice of preferences made by the state.

10/ The public appears to be well aware of the situation, as Figure 3 indicates.
} 
Table 7: Supporting a private supplementary programme of social security Question: 'To what extent do you support individual, private supplementary insurance against certain risks that would complement the current compulsory system of taxes and social benefits?'

Czech Republic, June 1999 ( $\mathrm{N}=1,319)$

\begin{tabular}{lccc} 
Individual supplementary insurance for: & Prefer & Accept & Refuse \\
\hline Higher pension & 35 & 48 & 6 \\
Early retirement & 23 & 49 & 11 \\
Better sickness benefits & 22 & 50 & 14 \\
Better healthcare & 17 & 45 & 25 \\
Security during unemployment & 14 & 44 & 25 \\
Secured income when taking care of small & & & \\
children or following a divorce & 15 & 42 & 20 \\
\hline
\end{tabular}

Note: 'Undecided' represents the percentage remaining to $100 \%$.

The requirement of reciprocity does not significantly differ according to the social characteristics of respondents, and depends only slightly on their political affiliation, with the demand for reciprocity being somewhat stronger among the right-wing respondents. ${ }^{11}$

Provided that the reciprocity of contributions and benefits is maintained, the Czech public shows comparatively greater willingness to share individual risks ${ }^{12}$, and thus its notion of solidarity in the social policy appears to depend on the reciprocity of social provisions among the public. While the Czech public strongly emphasised reciprocity of social policy measures, in the 1990s the actual reciprocity between social security contributions and social benefits was in fact declining. ${ }^{13}$ This has given rise to a relatively high need for individual, supplementary methods of insurance against social risks outside of the state social security system.

The majority of citizens find these methods to be a suitable complement to the basic system guaranteed by the state. The percentages of expressed support for private pensions and health care in the Czech Republic are significantly higher then they were, for example, in the United Kingdom at the end of the 1980s. Approximately 83\% of Czechs accept private supplementary insurance for old-age pensions, while only $63 \%$ of citizens in

11/ The Spearman's correlation coefficient equals 0.21 (significance 0.000 ).

12/ The Spearman's coefficient of correlation between the reciprocity index and risk sharing index equals 0.32 (significance 0.000 ). The reciprocity index was calculated as the average of requirements of reciprocity for individual benefits (as listed in Table 6). In the same fashion, the risk sharing index was calculated as the average of requirements of sharing risk for individual areas (as listed in Table 2).

13/ This is due to the relatively low 'ceilings' that hold for calculating social insurance benefits (unemployment, sickness and maternity benefits) or due to the principle of reducing the applicable income in the case of pensions. But in October 1999, the Czech Social Democratic government, with the support of the right-wing opposition in the Parliament, adopted a provision that leads to an increase in the sickness and unemployment benefits, particularly among the middle and higher income groups. 
the U.K. agreed to this idea in 1989. Moreover, $62 \%$ of Czechs accept private supplementary insurance for health care, while only 49\% of U.K. citizens in 1989 approved this idea [Taylor-Gooby 1991: 116].

Political orientation, opinions on the quality of the current social insurance system, and the requirement of reciprocity, form the guidelines for citizens' decisions about supporting private, supplementary methods. There is a clear general inclination to accept private insurance against social risks as a supplementary option; this tendency is in line with the trend towards a modest concept of social policy which was found at the level of principles and goals.

\section{Conclusions}

In this paper, the links between the preferred principles of social policy among the Czechs, their opinions on actual social policy, and their claims on the welfare state have been examined, and hypotheses have been presented on the factors influencing the concepts of legitimate social policy in the Czech Republic: social risks introduced by the recent transformation, increasing social inequalities, some restrictions on public budgets and social expenditures, and a radical shift in dominant political ideologies.

At the level of the general principles and goals important for social policy, the Czech public shows moderate demands regarding the scope of redistribution, and prefers redistribution principles that correspond to the concept of a limited (modest) welfare state: guaranteeing minimum subsistence; emphasising need, merits and individual efforts; expecting less elimination of inequalities through social policy measures. Individual gains prevail among the motives underpinning solidarity, though motives such as sympathy for the beneficiaries, feelings of moral duty toward society, and perceived benefits to society are also very important, particularly at the level of social policy principles. At the level of specific programmes, however, the willingness of Czech citizens to share social risks that differ on an individual basis is rather limited. While the structure of the motives of solidarity is very similar the motives discovered in the Netherlands, the willingness of the Czechs to redistribute individually different risks among those who are relatively more disadvantaged is somewhat lower than among the Dutch public.

Most citizens express a rather critical evaluation of trends in social policy and social policy expenditures. Social policy is thought to be deteriorating and expenditures are considered insufficient in many areas, though the views expressed by respondents depend on their political orientation. The great majority of Czechs complain about individual losses from redistribution within the social security system; this finding contrasts with the situation in the Netherlands, where the public's opinions are balanced around an average. The complaints Czechs make are apparently based on objective reasons, as the ratio of contributions paid to benefits received by citizens declined during the 1990s in all income groups.

The strong subjective feelings of individual losses stemming from social policy measures compared to the costs incurred by social policy suggest that citizens share moderate demands for the improvement of existing social provisions guaranteed by the state, despite their belief that welfare expenditures are insufficient. The Czech public - like the Dutch public - assumes that the welfare state is quite frequently abused. However, they do not in contrast to their Dutch counterparts - believe that the state system of social protection 
is well managed, effective or just. Czech citizens also show relatively strongly support for the introduction of private supplementary methods in the most costly areas of social policy, i.e. old-age pensions and health care. This is related to the fact that Czech citizens call for a higher degree of reciprocity between the individual costs of social policy and the individual benefits derived from it, more so than the Dutch public.

We can conclude that if the solidarity of citizens in social policy is motivated to a large extent by the assumption of individual gains to be had from social policy measures, each individual loss derived from the comparison between the payment made to the system and the individual benefit received from the system not only leads to a negative evaluation of the system, but also decreases the amount of trust and interest in it. Consequently, it leads to a search for other, more effective solutions, particularly in the form of private systems (with less solidarity), which protect individuals against rising social uncertainties. Moreover, the experience with implemented policies and their impact affects the trustworthiness of the entities offering and implementing the given programmes, i.e. the state and its institutions, and also affects the faith that the citizens have in their effectiveness. ${ }^{14}$ A cluster of mutually linked attitudes is then formed out of the relatively widespread belief among citizens in the frequent abuse of the welfare state system, the negative evaluation of the quality of the social policy programme and its management, the ability of the government to put social justice into practice, and subsequently, the decreasing willingness of citizens to share risks that differ on an individual basis.

TOMÁš SIROVÁtKa is director of the Institute for Social Issues at Masaryk University (Faculty of Social Studies) in Brno where he teaches courses on the labour market and social policy. His recent research includes a national study of the links between the labour market and social policy, the study of the legitimacy of social policy, and a comparative study of social assistance and income support policies in Central European countries. He has published the monograph Marginalizace na pracovním trhu (Labour Market Marginalisation, 1997), and edited the books Česká sociální politika na prahu 21. století: efektivnost, selhávání, legitimita (Czech Social Policy on the Eve of the 21. Century: Effectiveness, Failures, Legitimacy, 2000) and Menšiny a marginalizované skupiny v České republice (Minorities and Marginalised Groups in the Czech Republic, 2002).

\section{References}

Baldwin, P. 1990. Politics of Social Solidarity. Cambridge: Cambridge University Press.

Deutsch, M. 1975. 'Equity, Equality, and Need: What Determines Which Value Will Be Used As the Basis of Distributive Justice?' Journal of Social Issues 31: 137-149.

Ester, P., L. Halman, R. de Moor 1994. The Individualizing Society. Value Change in Europe and North America. Tilburg: Tilburg University Press.

\footnotetext{
14/ In this respect, it is important to note that a number of polling organisations have found that the trust in the state and public administration institutions (for it does not apply only to the social policy administration) has generally been low in the Czech Republic since 1990 [cf. Ester, Halman, and de Moor 1994].
} 
Ferge, Z. 1997. 'The Changed Welfare Paradigm: The Individualization of the Social.' Social Policy and Administration 31(1): 20-44.

Habermas, J. 1976. Legitimation Crisis. London: Heinemann.

Heclo, H. 1981. 'Toward a New Welfare State?' Pp. 383-406 in The Development of Welfare States in Europe and America, ed. by P. Flora and A. J. Heidenheimer. London and New Brunswick: Transaction Publishers.

Matějů, P. 1997. Beliefs about Distributive Justice and Social Change. The Czech Republic 1991-1995. Working papers of the project Social trends /1997. Prague: Institute of Sociology ASCR.

Miller, D. 1976. Social Justice. Oxford: Clarendon Press.

Offe, C. 1996. Modernity and the State: East, West. Cambridge: Polity Press.

Oorschot, W. van 1997. 'The Common Good, Nearness and Dependence. On Solidarity and Its Motives.' Working papers 12. Tilburg: Katholieke Universiteit Brabant.

Oorschot, W. van 1998. Dutch Public Opinion on Social Security. Centre for Research in Social Policy. Loughborough: Loughborough University.

Oorschot, W. van, T. Sirovátka, L. Rabušic 1999. 'Solidarita a podpora sociálnímu státu: srovnání České republiky a Nizozemí' [Solidarity and Support for the Welfare State: The Czech Republic and the Netherlands in Comparison]. Sociologický časopis 35(3): 247-267.

Pettersen, P.A. 1995. 'The Welfare State: The Security Dimension.' Pp. 198-233 in: Borre, O., Scarbrough, E. (eds): The Scope of Government. Oxford and New York: Oxford University Press.

Purkrábek, M. 1996. Verejná politika a její aktéŕi [Public Policy and Its Actors]. Prague: Fakulta sociálních věd UK.

Rabušic, L., T. Sirovátka 1999. 'Legitimacy of the Czech Welfare State.' Polish Sociological Review 126(2): 239-263.

Ringen, S. 1987. The Possibility of Politics. Oxford: Oxford University Press.

Rose, R., B. G. Peters 1978. Can Government Go Bankrupt? New York: Basic Books.

Sen, A. 1992. Inequality Re-examined. Oxford and New York: Oxford University Press.

Sirovátka, T. 1998. 'Social Transfers in the Period of Transformation and Their Effects.' Prague Economic Papers 7(4): 346-361.

Svalfors, S. 1999. Political Trust and Attitudes Towards Redistribution. A Comparison of Sweden and Norway. European Societies 1 (2): 241-268.

Svalfors, S., P. Taylor-Gooby 1999. The End of the Welfare State? London and New York: Routledge.

Taylor-Gooby, P. 1985. Public Opinion, Ideology and State Welfare. London: Routledge and Kegan Paul.

Taylor-Gooby, P. 1991. Social Change, Social Welfare and Social Science. New York: Harvester Wheatsheaf.

Večerník, J., P. Matějů (eds.) 1999, Ten Years of Rebuilding Capitalism: Czech Society After 1989. Praha: Academia.

Večerník, J., P. Burdová 1999. 'Income redistribution through taxes and social benefits.' Pp. 137-156 in Večerník, J., P. Matějů 1999.

Večerník, J. 2002. „Přerozdělování př́ijmů daněmi a dávkami v ČR: jeho proměny a reflexe po roce 1989“. [Income Redistribution Via Taxes and Benefits in the CR: Change and Perception after 1989]. Finance a úvěr 52 (1): 4-22. English version on http://www.financeauver.org 
Vlachová, K. 1999. 'The Crystallization of Political Attitudes and Orientations.' Pp. 251-294 in Večerník, J., P. Matějů 1999.

Wilenski, H. L. 1975. The Welfare State and Equality: Structural and Ideological Roots of Public Expenditures. Berkeley, CA: University of California Press. 